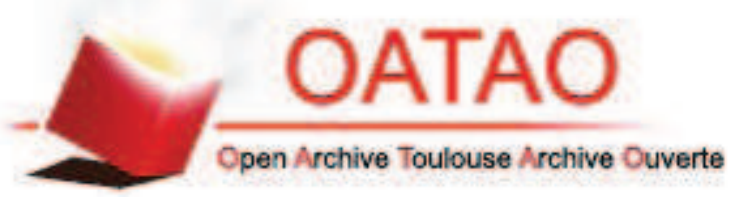

This is an author-deposited version published in : http://oatao.univ-toulouse.fr/ Eprints ID : 9677

To link to this article : DOI: $10.1111 / \mathrm{j} .1365-2486.2010 .02185 . \mathrm{x}$ http://doi.wiley.com/10.1111/j.1365-2486.2010.02185.x

To cite this version: Ferreira, Veronica and Chauvet, Eric Synergistic effects
of water temperature and dissolved nutrients on litter decomposition and
associated fungi. (2011) Global Change Biology, vol. 17 ( $\mathrm{n}^{\circ}$ 1). pp. 551-564.
ISSN 1354-1013

Any correspondance concerning this service should be sent to the repository administrator: staff-oatao@,1istes-diff.inp-toulouse.fr 


\title{
Synergistic effects of water temperature and dissolved nutrients on litter decomposition and associated fungi
}

\author{
VERÓNICA FERREIRA* and ERIC CHAUVET † \\ *IMAR-CMA, Department of Life Sciences, University of Coimbra, PO Box 3046, 3001-401 Coimbra, Portugal, †EcoLab \\ (Laboratoire d'écologie fonctionnelle), Université de Toulouse; UPS, INPT, 29 rue Jeanne Marvig, F-31055 Toulouse, France, \\ $\ddagger$ CNRS, EcoLab, F-31055 Toulouse, France
}

\begin{abstract}
In woodland streams, the decomposition of allochthonous organic matter constitutes a fundamental ecosystem process, where aquatic hyphomycetes play a pivotal role. It is therefore greatly affected by water temperature and nutrient concentrations. The individual effects of these factors on the decomposition of litter have been studied previously. However, in the climate warming scenario predicted for this century, water temperature and nutrient concentrations are expected to increase simultaneously, and their combined effects on litter decomposition and associated biological activity remains unevaluated. In this study, we addressed the individual and combined effects of water temperature (three levels) and nutrient concentrations (two levels) on the decomposition of alder leaves and associated aquatic hyphomycetes in microcosms. Decomposition rates across treatments varied between 0.0041 day $^{-1}$ at $5^{\circ} \mathrm{C}$ and low nutrient level and $0.0100 \mathrm{day}^{-1}$ at $15^{\circ} \mathrm{C}$ and high nutrient level. The stimulation of biological variables at high nutrients and temperatures indicates that nutrient enrichment of streams might have a higher stimulatory effect on fungal performance and decomposition rates under a warming scenario than at present. The stimulation of fungal biomass and sporulation with increasing temperature at both nutrient levels shows that increases in water temperature might enhance fungal growth and reproduction in both oligotrophic and eutrophic streams. The stimulation of fungal respiration and litter decomposition with increasing temperature at high nutrients indicates that stimulation of carbon mineralization will probably occur at eutrophied streams, while oligotrophic conditions seem to be 'protected' from warming. All biological variables were stimulated when both factors increased, as a result of synergistic interactions between factors. Increased water temperature and nutrient level also affected the structure of aquatic hyphomycete assemblages. It is plausible that if water quality of presently eutrophied streams is improved, the potential stimulatory effects of future increases in water temperature on aquatic biota and processes might be mitigated.
\end{abstract}

Keywords: aquatic hyphomycetes, ecosystem functioning, global change, interactions, litter decomposition, nutrient enrichment, streams, temperature

\begin{abstract}
Introduction
Earth is presently going through a warming period, and simulations considering a doubling in atmospheric $\mathrm{CO}_{2}$ predict a $1.1-6.4^{\circ} \mathrm{C}$ increase in air temperature by the year 2100 (IPCC, 2007). Water temperature of streams and rivers is expected to mirror this increase (Stefan \& Sinokrot, 1993; Eaton \& Scheller, 1996), which may lead to altered community structure (Hogg \& Williams, 1996; Mouthon \& Daufresne, 2006), species distribution (Winterbourn, 1969; Eaton \& Scheller, 1996; Castella et al., 2001), interspecific relationships (Webster et al., 1976; Beisner et al., 1997; Mouritsen et al., 2005; Jiang \& Morin, 2007), biodiversity (Petchey et al., 1999; Castella et al., 2001) and ecological processes (Petchey et al., 1999; Baulch et al., 2005).
\end{abstract}

Correspondence: V. Ferreira, tel. + 351239855 760, fax + 351239 855 789, e-mail: veronica@ci.uc.pt
Small, moderate to high latitude/altitude forest streams, where water temperature is generally low, are particularly sensitive to temperature increases (Stefan \& Sinokrot, 1993). In these streams, the primary source of carbon and energy for aquatic food webs is terrestrially derived organic matter supplied by the riparian vegetation, whose shade also limits primary production (Vannote et al., 1980). Decomposition of this organic matter is carried out mainly by aquatic hyphomycetes and shredding invertebrates (Hieber \& Gessner, 2002; Pascoal \& Cássio, 2004), through mineralization, incorporation into biomass and conversion into fine particulate organic matter (González \& Graça, 2003; Gulis \& Suberkropp, 2003b,c; Pascoal \& Cássio, 2004). Litter decomposition, being primarily a biological process, is expected to be affected by increased water temperature. Correlative studies have demonstrated a positive relationship between water temperature and decomposition rates of litter incubated along altitudinal or latitudinal gradients (Irons et al., 1994; Fabre \& Chauvet, 
1998), probably mediated by temperature effects on the biota (Fabre \& Chauvet, 1998). Simulations also predict higher decomposition rates with increased water temperature, through enhancement of invertebrate and microbial activity (Buzby \& Perry, 2000). Higher water temperatures have been shown to affect litter decomposition in laboratory experiments, both directly, by promoting leaching of soluble compounds (Chergui \& Pattee, 1990), and indirectly, by stimulating fragmentation and consumption by selected invertebrate shredders (González \& Graça, 2003; Azevedo-Pereira et al., 2006) and by enhancing microbial activity (Carpenter \& Adams, 1979). High temperatures also stimulate production of fungal assemblages associated with leaves (Suberkropp \& Weyers, 1996), and growth and sporulation by some species of aquatic hyphomycetes cultivated individually (Koske \& Duncan, 1974; Graça \& Ferreira, 1995; Chauvet \& Suberkropp, 1998; Rajashekar \& Kaveriappa, 2000; Dang et al., 2009), which can result in accelerated decomposition rates. However, species have a temperature tolerance range below and above which their activity is reduced or suppressed. In face of the predicted increases in water temperature many species of invertebrates (Quinn et al., 1994) and fungi (Koske \& Duncan, 1974; Rajashekar \& Kaveriappa, 2000) may have their activity inhibited, making it difficult to predict the response of the decomposition process in streams under a global warming scenario. In addition, the influence of modified interspecific interactions is largely unknown (Webster et al., 1976).

Additionally, there are several factors that are associated with increased temperature, which might modulate its effects on stream biota and processes. One such factor is increased evapotranspiration, and consequently increased pollutant and nutrient concentrations in water bodies (Murdoch et al., 2000). This, associated with increasing needs for water and production of wastewater by a growing human population, will result in decreased ecological status of freshwaters, i.e. decreased ability to provide ecosystem services as water purification. The effects of dissolved nutrients on the decomposition of submerged litter and associated biological activity have been well studied. Nutrient enrichment generally stimulates litter decomposition and associated biota (Elwood et al., 1981; Suberkropp \& Chauvet, 1995; Rosemond et al., 2002; Gulis \& Suberkropp, 2003a; Niyogi et al., 2003; Pascoal et al., 2003; Gulis et al., 2004, 2006; Ferreira et al., 2006b). In streams where a given inorganic nutrient (i.e. $\mathrm{N}$ or $\mathrm{P}$ ) is not limiting, further increases in its concentration in water may however not enhance litter decomposition or activity of associated microbes (Grattan \& Suberkropp, 2001; Abelho \& Graça, 2006; Baldy et al., 2007). Also, when increases in dissolved nutrients occur simultaneously with variation in other factors (e.g. increases in sedimentation, decreases in dissolved $\mathrm{O}_{2}$ ) their stimulatory effect might be offset (Pascoal \& Cássio, 2004). Inhibition of decomposition rates might occur when increases in dissolved nutrients reach toxic levels (Lecerf et al., 2006).

The effect of interactions between increased water temperature and nutrient concentrations on litter decomposition and associated biological activity remains to be assessed. Nonetheless, evidence from other systems suggests that the effects of factors associated with global changes acting in combination might not be predictable from the effects of factors considered individually (Rozema et al., 1997; Hoffman et al., 2003; Przeslawski et al., 2005). In this study, we addressed the effects of water temperature (three levels) and nutrient concentrations (two levels) on the decomposition of alder leaves, and associated aquatic hyphomycete biomass, activity and assemblage structure in simulated stream microcosms, in a complete factorial design. As the rate of biological processes is dependent on temperature, since they are basically enzyme driven (Brown et al., 2004), and fungi can retrieve nutrients from both the substrate and the water (Suberkropp, 1998), we predict that fungal biomass and activity, and consequently decomposition rates, will increase with temperature and nutrient concentrations. Given that aquatic hyphomycetes exhibit temperature and nutrients optima (Gulis \& Suberkropp, 2003a; Pascoal et al., 2005a; Ferreira et al., 2006b; Artigas et al., 2008), changes in the structure of the assemblages are anticipated.

\section{Materials and methods}

\section{Fungal species assemblage}

An assemblage of six species of aquatic hyphomycetes was used, as representative of fungal diversity found on a single leaf decomposing in natural streams (Bärlocher, 1992). Strains were isolated from single conidia trapped in naturally occurring foam, or released from leaf accumulations, collected from a lowland stream in central Portugal [Ribeira do Botão; $40^{\circ} 18^{\prime} 22^{\prime \prime} \mathrm{N}, \quad 8^{\circ} 23^{\prime} 37^{\prime \prime} \mathrm{W}$; Articulospora tetracladia Ingold (ARTE)], a Mediterranean stream in the French Pyrenees [Maureillas; $42^{\circ} 28^{\prime} 18^{\prime \prime} \mathrm{N}, 2^{\circ} 47^{\prime} 57^{\prime \prime} \mathrm{E}$; Clavariopsis aquatica de Wildeman (CLAQ), Flagellospora curoula Ingold (FLCU) and Tetracladium marchalianum de Wildeman (TEMA)] and a temperate mountain stream in the Massif Central, SW France [Oreval; 43 $26^{\prime} 19^{\prime \prime} \mathrm{N}, 2^{\circ} 5^{\prime} 41^{\prime \prime} \mathrm{E}$; Heliscus lugdunensis Saccardo \& Thérry (HELU) and Tumularia aquatica (Ingold) Descals \& Marvanová (TUAQ)]. Growing colonies were kept at $15^{\circ} \mathrm{C}$, in $9 \mathrm{~cm}$ diameter Petri dishes with $\sim 10 \mathrm{~mL}$ of growth medium (10 $\mathrm{g}$ malt and $20 \mathrm{~g}$ agar per liter of sterile distilled water), until they were used to induce conidial production. Conidial inoculations $\left(<1\right.$-day-old) were produced at $15^{\circ} \mathrm{C}$, by incubation of agar plugs taken from the leading edge of 7- to 14-day-old colonies (either grown from an individual agar plug or from conidia spread over a Petri dish) in $25 \mathrm{~mL}$ of nutrient solution 
(75.5 mg $\mathrm{CaCl}_{2}, 10 \mathrm{mg} \mathrm{MgSO}_{4} \cdot 7 \mathrm{H}_{2} \mathrm{O}, 0.5 \mathrm{~g}$ 3-morpholinopropanesulfonic acid (MOPS), $0.55 \mathrm{mg} \mathrm{K}_{2} \mathrm{HPO}_{4}$ and $100 \mathrm{mg} \mathrm{KNO}$ per liter of sterile distilled water), on an orbital shaker (100 rpm). An aliquot of each specific conidial suspension, based on conidial numbers, was used to make a combined conidial suspension to inoculate each microcosm.

\section{Microcosms, medium and experimental setup}

Alder [Alnus glutinosa (L.) Gaertner] leaf discs were incubated in laboratory microcosms designed to simulate stream conditions (Suberkropp, 1991). Each microcosm consisted of a $50 \mathrm{~mL}$ glass chamber aerated from the bottom by a continuous air flow $\left(80-100 \mathrm{~mL} \mathrm{~min}^{-1}\right)$, which creates turbulence and keeps the leaf discs in permanent agitation. A tap at the bottom allowed for the aseptic drainage of the chamber and recovery of the conidial suspension. Fresh medium $(40 \mathrm{~mL})$ was added to microcosms through the open top which was otherwise closed with a glass cap. Microcosms were incubated in the dark at three temperatures $\left(5,10\right.$ and $\left.15^{\circ} \mathrm{C}\right)$, for the duration of the experiment.

Half of the microcosms at each temperature were filled with a low nutrient concentrations solution (low NP level treatment) and half with a high nutrient concentrations solution (high NP level treatment). The low nutrient solution was composed of $75.5 \mathrm{mg} \mathrm{CaCl}_{2}, 10 \mathrm{mg} \mathrm{MgSO}_{4} \cdot 7 \mathrm{H}_{2} \mathrm{O}, 0.5 \mathrm{~g}$ MOPS, $0.055 \mathrm{mg}$ $\mathrm{K}_{2} \mathrm{HPO}_{4}$ and $10 \mathrm{mg} \mathrm{KNO}_{3}$ per liter of sterile distilled water $\left(=0.01 \mathrm{mg} \mathrm{PO}_{4}-\mathrm{PL}^{-1}\right.$ and $\left.1.39 \mathrm{mg} \mathrm{NO}_{3}-\mathrm{NL}^{-1}\right)$, while the high nutrient solution was amended with $0.55 \mathrm{mg} \mathrm{K}_{2} \mathrm{HPO}_{4}$ and $100 \mathrm{mg} \mathrm{KNO}_{3}\left(=0.10 \mathrm{mg} \mathrm{PO}_{4}-\mathrm{PL}^{-1}\right.$ and $13.86 \mathrm{mg} \mathrm{NO}_{3}-\mathrm{NL}^{-1}$ ) (Dang et al., 2005). The phosphorus limitation in the solutions $(\mathrm{N}: \mathrm{P}=141)$ was intended to mimic the trophic conditions of most streams (Grattan \& Suberkropp, 2001), although there are streams in which nitrogen naturally is the limiting nutrient (Ferreira et al., 2006b). There were 12 replicate microcosms for each of the six temperature-nutrient treatments.

Alder leaves collected just after abscission on December 30, 2006 at Gibel, Midi-Pyrenees, France $\left(43^{\circ} 17^{\prime} 35^{\prime \prime} \mathrm{N}, 1^{\circ} 40^{\prime} 51^{\prime \prime} \mathrm{E}\right)$, and dried at room temperature, were moistened with distilled water and left to rehydrate overnight. Leaf discs were cut with a $12 \mathrm{~mm}$ diameter cork borer and oven dried $\left(65^{\circ} \mathrm{C}\right)$ during 3 days. Batches of 20 leaf discs were frozen overnight at $-20^{\circ} \mathrm{C}$, lyophilized $(20 \mathrm{~h})$, weighed $( \pm 0.1 \mathrm{mg})$ to determine initial dry mass (DM), placed inside glass tubes with an aliquot of distilled water and autoclaved $\left(20 \mathrm{~min}\right.$ at $\left.121^{\circ} \mathrm{C}\right)$. Seven batches of 20 leaf discs were given the same treatment and were used to create a correction factor for mass loss due to leaching during sterilization. Sterilized microcosm $(30 \mathrm{~min}$ at $121^{\circ} \mathrm{C}$ ) were filled with $40 \mathrm{~mL}$ of the low or high nutrient solutions, received the corresponding leaf discs, were distributed by three incubator chambers $\left(5,10\right.$ and $\left.15^{\circ} \mathrm{C}\right)$, and aerated for $24 \mathrm{~h}$. Nutrient solutions were changed, the microcosms inoculated with a total of 4800 conidia equally partitioned among all species of the aquatic hyphomycete assemblage, aerated for $10 \mathrm{~min}$, left to rest for ca. $2 \mathrm{~h}$, and aerated again. The nutrient solutions were replaced after $24 \mathrm{~h}$ and then every 3 days for the duration of the experiment (43 days). All manipulations of microcosms took place in a flow cabinet.

\section{Fungal sporulation}

Each of the 14 times the nutrient solutions were changed, the conidial suspensions from three microcosms (the same over time) from each treatment were stored into $50 \mathrm{~mL}$ centrifuge tubes, sample volume was adjusted to $42 \mathrm{~mL}$ with distilled water and preserved with $3 \mathrm{~mL}$ of $35 \%$ formalin. Additionally, after 10, 16, 28 and 43 days, three microcosms from each treatment were sacrificed, and the conidial suspensions preserved as above. When preparing filters for conidial counting and identification, $150 \mu \mathrm{L}$ of polyethylene glycol $p$-(1,1,3,3-tetramethylbutyl)-phenyl ether (Triton X-100, 0.5\%) were added to the suspension, mixed with a magnetic stirring bar, to ensure a uniform distribution of conidia, and an aliquot of the suspension was filtered (Millipore SMWP, pore size $5 \mu \mathrm{m}$ ). Filters were stained with $0.08 \%$ trypan blue in $60 \%$ lactic acid, and spores were identified and counted under a compound microscope at $\times 320$ (Graça et al., 2005). For sacrificed microcosms, sporulation rates were expressed as number of conidia $\mathrm{mg}^{-1} \mathrm{DMday}^{-1}$. For microcosms repeatedly sampled throughout time, results were expressed as number of conidia microcosm ${ }^{-1}$ and as mg conidia microcosm ${ }^{-1}$. The total conidial mass at each sampling date was calculated by multiplying the number of conidia from each species by the average mass of individual conidia obtained from the literature (Chauvet \& Suberkropp, 1998) or calculated from biovolume data (Bärlocher \& Schweizer, 1983) assuming a $70 \%$ water content. Cumulative conidial mass production over time was calculated by summing up the total conidial mass at the preceding sampling dates.

\section{Oxygen consumption}

A subset of five leaf discs from each sacrificed microcosm was used to determine fungal oxygen consumption rates using a closed six-channel dissolved oxygen measuring system (Strathkelvin 928 System, North Lanarkshire, Scotland) connected to a computer. The oxygen electrodes were calibrated against a $4 \%$ sodium sulfite solution prepared immediately before use $(0 \%$ $\mathrm{O}_{2}$ ), and a $100 \% \mathrm{O}_{2}$ saturated low or high nutrient solution at the target temperature. Leaf discs were incubated in $3 \mathrm{~mL}$ volume chambers filled with $100 \% \mathrm{O}_{2}$ saturated low or high nutrient solution, homogenized with a magnetic stirring bar, kept at the target temperature of 5,10 or $15^{\circ} \mathrm{C}$ by circulation of water originating from a temperature-controlled water bath. Additional chambers without leaf discs were used as controls. After $1 \mathrm{~h}$ trial, leaf discs were enclosed in small sterile zip lock bags and promptly frozen at $-20^{\circ} \mathrm{C}$ for later DM determination and ergosterol extraction. Oxygen consumption rates were determined by the difference in the oxygen concentration in the sample and the control over a $20 \mathrm{~min}$ interval and corrected for the chamber's volume, time and discs mass. Results were expressed as $\mathrm{mg} \mathrm{O}_{2} \mathrm{~g}^{-1} \mathrm{DMh}^{-1}$.

\section{Mass loss and mycelial biomass}

The remaining 15 leaf discs from each microcosm were enclosed in small sterile zip lock bags and promptly frozen at $-20^{\circ} \mathrm{C}$. All 20 leaf discs from each microcosm were combined, lyophilized, 
promptly weighed $( \pm 0.1 \mathrm{mg})$ to determine DM remaining, and used for ergosterol extraction as a surrogate for mycelial biomass (Gessner \& Chauvet, 1993; Graça et al., 2005). Lipid extraction and saponification were carried out in $5 \mathrm{~mL} \mathrm{KOH} /$ methanol $\left(8 \mathrm{~g} \mathrm{~L}^{-1}\right)$ at $80^{\circ} \mathrm{C}$ for $30 \mathrm{~min}$. The extract was then purified by solid phase extraction (Waters Oasis ${ }^{\circledR}$ HLB 3cc cartridges, Waters Corp., Milford, MA, USA; Graça et al., 2005). Ergosterol was quantified by HPLC (HPLC pump 422, HPLC detector 432, HPLC autosampler 360; Kontron Inst., Neufahru, Germany) by measuring absorbance at $282 \mathrm{~nm}$. The HPLC detector was equipped with a FLT $0.5 \mu \mathrm{m}$ A-316 precolumn (Upchurch Sci., Oak Harbour, WA, USA) and a LispRP 18-5 $250 \times 4.6 \mathrm{~mm}$ column (Thermo-Hypersil Keystone, Bellefonte, PA, USA) maintained at $33^{\circ} \mathrm{C}$. The mobile phase was $100 \%$ methanol and the flow rate was set to $1.4 \mathrm{~mL} \mathrm{~min}^{-1}$. Ergosterol was converted into mycelial biomass using specific conversion factors for ARTE, CLAQ, FLCU and TEMA, and $5.5 \mu \mathrm{g}$ ergosterol $\mathrm{mg}^{-1}$ mycelial biomass for HELU and TUAQ (Gessner \& Chauvet, 1993), applied to the relative contribution of each species to total ergosterol mass based on specific contribution to total conidial production. Results were expressed as mg mycelial biomass $\mathrm{g}^{-1} \mathrm{DM}$.

\section{Fungal carbon budgets}

Fungal carbon (C) budgets were calculated assuming a 50\% C content of leaf, conidia and mycelial DM and a respiratory quotient of 1 (Gulis \& Suberkropp, 2003b). The cumulative fungal $C$ production was calculated for day 43 by summing up the cumulative conidial $\mathrm{C}$ production and the mycelial $\mathrm{C}$ production, the sum of which was maximum at day 43 . The fungal yield coefficient $(\%)$ was calculated as cumulative fungal C production $(\%) /$ leaf $C$ mass loss $(\%) \times 100$. The fungal production efficiency $(\%)$ was calculated as cumulative fungal $\mathrm{C}$ production $\left(\mathrm{mg} \mathrm{g}^{-1}\right) /$ (cumulative fungal $\mathrm{C}$ production $\left(\mathrm{mg} \mathrm{g}^{-1}\right)+$ cumulative $C$ respired $\left.\left(\mathrm{mgg}^{-1}\right)\right) \times 100$. The explained leaf $\mathrm{C}$ mass loss by a given fungal activity (conidial C production, mycelial C production or mineralization; \%) was calculated as $C$ allocated to this fungal activity/leaf $C$ mass loss $\times 100$. The total explained leaf $\mathrm{C}$ mass loss $(\%)$ resulted from the sum of leaf $\mathrm{C}$ mass loss due to conidial $\mathrm{C}$ production, mycelial C production and mineralization (Baldy et al., 1995; Gulis \& Suberkropp, 2003b,c).

\section{Data treatment}

Decomposition rates of alder leaf discs were calculated assuming (a) an exponential decay, by linear regression of the Ln transformed negative exponential model $M_{\mathrm{t}}=M_{\mathrm{o}} \times \mathrm{e}^{-k \mathrm{t}}$ (where $M_{\mathrm{o}}$ is the initial mass, $M_{\mathrm{t}}$ is the remaining mass at time $t$ and $k$ is the decomposition rate) and (b) a linear decay, by regression of the linear model $M_{\mathrm{t}}=M_{\mathrm{o}} \times(1-k \times \mathrm{t})$ (Pozo \& Colino, 1992). In both cases, a fixed intercept was used at $M_{\mathrm{o}}=0$ or $M_{\mathrm{o}}=1$, for the exponential and linear model, respectively. Although the decomposition rates derived from the exponential model might be useful for comparisons with published literature, where this is the most commonly used model, further analysis were performed considering only a linear decay, since the Akaike Information Criterion (AIK) and the Bayesian Information Criterion (BIC) as tools for model selection gave lower values for the linear model than for the exponential one (AIK $=-147$ vs. -123 and $\mathrm{BIC}=-143$ vs. -118), indicating that the linear model fits the data better. Slopes were compared among treatments by ANCOVA with time as continuous variable and temperature and nutrient level as categorical variables, followed by Tukey's Honest Significant Difference (HSD). The relationship between remaining mass (\% initial mass) after 43 days and water temperature for the low and high nutrient levels was assessed by linear regression.

The sensitivities of decomposition rates to temperature were calculated as $Q_{10-q}$ values: $Q_{10-q}=\left(t_{\mathrm{c}} / t_{\mathrm{w}}\right)^{\left(10 /\left(T_{\mathrm{c}} / T_{\mathrm{w}}\right)\right)}$, where $t_{\mathrm{c}}$ and $t_{\mathrm{w}}$ are the time (d) at the cooler and warmer temperature to decompose $20 \% \mathrm{DM}$, respectively, and $T_{\mathrm{w}}$ and $T_{\mathrm{c}}$ are the warmer and cooler temperature $\left({ }^{\circ} \mathrm{C}\right)$, respectively (Conant et al., 2008). These have the advantage over $Q_{10}$ values of allowing determination of sensitivities of decomposition to temperature for temperature intervals different from $10^{\circ} \mathrm{C}$, and of keeping the substrate quality $(q)$ consistent between temperatures and thus eliminating changes on litter quality as a source of variation on sensitivities to temperature (Conant et al., 2008).

Fungal oxygen consumption, biomass and sporulation rates associated with alder discs from the sacrificed microcosms were compared among treatments by three-way ANOVAs (time, temperature and nutrient level as categorical variables), followed by Tukey's HSD. Total number of conidia, total mass of conidia and sporulating species richness per microcosm determined over the 14 sampling dates were compared among treatments by repeated measures ANOVAs, followed by Tukey's HSD. Cumulative conidial production (mass and number) was compared among treatments by ANCOVA, followed by Tukey's HSD. The cumulative number of conidia produced by each aquatic hyphomycete species by day 43 was compared among treatments by two-way ANOVAs (temperature and nutrient level as categorical variables), followed by Tukey's HSD. For the common sampling dates (day 10, 16, 28 and 43) there was no significant difference in conidial production between the three sacrificed microcosms and the three microcosms sampled though time, for any treatment (one-way ANOVA, $P>0.08$ ).

Fungal assemblages over all sampling dates were analyzed by nonmetric multidimensional scaling ordination (NMDS) based on Bray Curtis similarity index of $\log (x+1)$ transformed conidial abundance data (PRIMER v6; Clarke \& Gorley, 2001). However, the effect of time in determining the structure of the assemblage (analysis of similarity, ANOSIM) hid the potential effects of temperature and nutrient level. To overcome this, fungal assemblages were analyzed by sampling date, and two-way ANOSIM performed with temperature and nutrient level as factors.

Leaf $\mathrm{C}$ mass loss due to conidial production, mycelial production, mineralization, total mass loss due to overall fungal activities, yield coefficient and production efficiency were compared among treatments by two-way ANOVAs (temperature and nutrient level as categorical variables), followed by Tukey's HSD. Mass loss due to overall fungal activities was arcsine-square root transformed.

Data were $\log (x+1)$ transformed when necessary to achieve normality and homoscedasticity, unless otherwise indicated. All analyses were performed with STATISTICA 6 software unless otherwise indicated. 
(a)
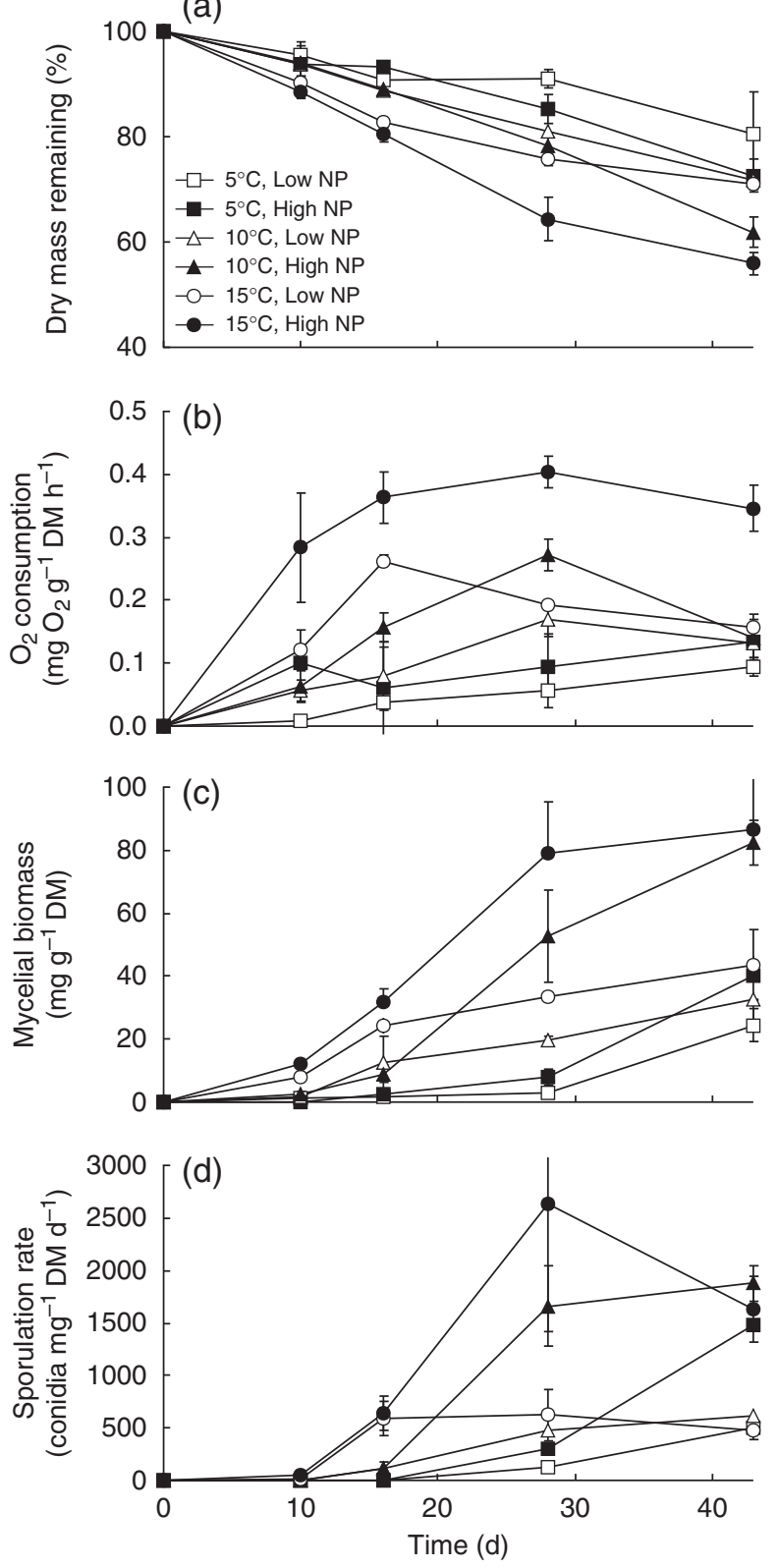

Fig. 1 Dry mass remaining of alder leaf discs (a), fungal oxygen consumption (b), mycelial biomass (c) and fungal sporulation rate (d) associated with alder leaf discs incubated in microcosms at three temperatures and two NP levels for 43 days. Data are from sacrificed microcosms and treatments are as in Table 1. Values are averages $\pm 1 \mathrm{SE}$.

\section{Results}

Mass loss

Mass loss of alder leaf discs after incubation in simulated stream microcosms for 43 days varied between $19 \%$ (at $5{ }^{\circ} \mathrm{C}$ and low NP level) and $44 \%$ (at $15^{\circ} \mathrm{C}$ and
Table 1 Decomposition rates $\left(\right.$ day $\left.^{-1}\right)$ of alder leaf discs incubated in microcosms at 5,10 or $15^{\circ} \mathrm{C}$ and low or high NP levels for 43 days, and coefficient of determination of the regression

\begin{tabular}{|c|c|c|c|c|c|}
\hline \multirow{2}{*}{$\begin{array}{l}\text { Temperature } \\
\left({ }^{\circ} \mathrm{C}\right)\end{array}$} & \multirow[b]{2}{*}{ NP level } & \multicolumn{2}{|c|}{$\begin{array}{l}\text { Exponential } \\
\text { model }\end{array}$} & \multicolumn{2}{|c|}{ Linear model } \\
\hline & & $k$ & $R^{2}$ & $k$ & $R^{2}$ \\
\hline \multirow[t]{2}{*}{5} & Low NP & $0.0048^{\mathrm{a}}$ & 0.38 & $0.0041^{\mathrm{a}}$ & 0.39 \\
\hline & High NP & $0.0067^{\mathrm{ab}}$ & 0.79 & $0.0067^{\mathrm{ab}}$ & 0.83 \\
\hline \multirow[t]{2}{*}{10} & Low NP & $0.0076^{\mathrm{ab}}$ & 0.97 & $0.0066^{\mathrm{abc}}$ & 0.97 \\
\hline & High NP & $0.0101^{\mathrm{b}}$ & 0.85 & $0.0097^{\mathrm{bc}}$ & 0.90 \\
\hline \multirow[t]{2}{*}{15} & Low NP & $0.0089^{\mathrm{b}}$ & 0.81 & $0.0055^{\mathrm{c}}$ & 0.88 \\
\hline & High NP & $0.0141^{\mathrm{c}}$ & 0.89 & $0.0100^{\mathrm{d}}$ & 0.89 \\
\hline
\end{tabular}

Treatments with the same letter are not significantly different (Tukey's HSD, $P>0.05$ ).

high NP level) (Fig. 1a), which translated into decomposition rates between 0.0041 and 0.0100 day $^{-1}$ (linear model; Table 1). Decomposition rates were stimulated by high NP level only at $15^{\circ} \mathrm{C}\left(0.0055 \mathrm{day}^{-1}\right.$ at low NP vs. 0.0100 day $^{-1}$ at high NP; Tukey's HSD, $P=0.008$ ); for both low and high NP levels, decomposition rates were faster at $15^{\circ} \mathrm{C}$ than at lower temperatures $\left(15>5^{\circ} \mathrm{C}\right.$ at low NP; $15>5^{\circ} \mathrm{C}$ and $15>10^{\circ} \mathrm{C}$ at high NP; Tukey's HSD, $P<0.002$; Table 1). Additionally, when temperature and NP level were increased simultaneously simulating a future scenario of both warming and eutrophication in winter (increase from $5{ }^{\circ} \mathrm{C}$ and low NP to $10^{\circ} \mathrm{C}$ and high $\mathrm{NP}$ ) or spring (increase from $10^{\circ} \mathrm{C}$ and low NP to $15^{\circ} \mathrm{C}$ and high NP) decomposition rates also increased (Tukey's HSD, $P<0.001$; Table 1). This increase was however higher than that predicted from the sum of the effects of both factors considered individually (0.0097 day ${ }^{-1}$ observed vs. 0.0092 day $^{-1}$ predicted for winter scenario, and 0.0100 day $^{-1}$ observed vs. 0.0086 day $^{-1}$ predicted for spring scenario). Leaf discs mass loss at high NP level after 43 days increased with increasing temperature (linear regression, $R^{2}=0.74$ and $P=0.003$ ), while at low NP level no relationship was found (linear regression, $R^{2}=0.24$ and $P=0.182$ ).

The sensitivity of litter decomposition to temperature, although overall low, depended on nutrient level and temperature interval. Decomposition rates at low NP level were more stimulated than decomposition rates at high NP level when temperature increased from 5 to $10^{\circ} \mathrm{C}\left(Q_{10-q}=2.62\right.$ vs. 2.10$)$, while an increase in temperature from 10 to $15^{\circ} \mathrm{C}$ almost did not had an effect on decomposition rates at high NP level $\left(Q_{10-q}=1.06\right)$ and inhibited those at low NP level $\left(Q_{10-q}=0.70\right)$. When temperature increased from 5 to $15^{\circ} \mathrm{C}$ decomposition rates were slightly more stimulated at high than at low NP level $\left(Q_{10-q}=1.49\right.$ vs. 1.36$)$. 
Table 2 Summary table for three-way ANOvAs performed on fungal oxygen consumption, mycelial biomass [log $(x+1)$ transformed], and sporulation rates $[\log (x+1)$ transformed], associated with alder discs incubated in microcosms at three temperatures and two NP levels for 43 days

\begin{tabular}{|c|c|c|c|c|c|c|c|}
\hline & \multirow[b]{2}{*}{$\mathrm{df}$} & \multicolumn{2}{|c|}{$\mathrm{O}_{2}$ consumption } & \multicolumn{2}{|c|}{ Mycelial biomass } & \multicolumn{2}{|c|}{ Sporulation rate } \\
\hline & & $F$ & $P$ & $F$ & $P$ & $F$ & $P$ \\
\hline \multicolumn{8}{|l|}{ Three-way ANOVA } \\
\hline Intercept & 1 & 496.6 & $<0.001$ & 3237.2 & $<0.001$ & 3383.0 & $<0.001$ \\
\hline Temperature & 2 & 51.0 & $<0.001$ & 128.3 & $<0.001$ & 95.0 & $<0.001$ \\
\hline NP level & 1 & 24.2 & $<0.001$ & 20.1 & $<0.001$ & 35.3 & $<0.001$ \\
\hline Time & 3 & 7.5 & $<0.001$ & 145.2 & $<0.001$ & 255.9 & $<0.001$ \\
\hline Temperature $\times$ NP level & 2 & 10.9 & $<0.001$ & 1.9 & 0.155 & 1.1 & 0.336 \\
\hline Temperature $\times$ time & 6 & 2.6 & 0.033 & 7.6 & $<0.001$ & 20.2 & $<0.001$ \\
\hline NP level $\times$ time & 3 & 2.3 & 0.095 & 4.5 & 0.007 & 0.7 & 0.580 \\
\hline Temperature $\times$ NP level $\times$ time & 6 & 1.6 & 0.167 & 1.3 & 0.274 & 0.9 & 0.534 \\
\hline Error & 43 & & & & & & \\
\hline \multicolumn{8}{|l|}{ Tukey's HSD } \\
\hline $5^{\circ} \mathrm{C}$, low NP & & & a & & a & & a \\
\hline $5^{\circ} \mathrm{C}$, high NP & & & $a b$ & & a & & $a b$ \\
\hline $10^{\circ} \mathrm{C}$, low NP & & & $a b c$ & & $\mathrm{~b}$ & & $\mathrm{~b}$ \\
\hline $10^{\circ} \mathrm{C}$, high $\mathrm{NP}$ & & & $\mathrm{bc}$ & & c & & $\mathrm{c}$ \\
\hline $15^{\circ} \mathrm{C}$, low $\mathrm{NP}$ & & & c & & c & & c \\
\hline $15^{\circ} \mathrm{C}$, high NP & & & $\mathrm{d}$ & & $\mathrm{d}$ & & $\mathrm{d}$ \\
\hline
\end{tabular}

Tukey's HSD are presented, with treatments with the same letter not being significantly different $(P>0.05)$. Data are from sacrificed microcosms and treatments are as in Table 1.

\section{Oxygen consumption}

Oxygen consumption by fungi generally increased until a peak was reached (days $10-28$ ), except at $5{ }^{\circ} \mathrm{C}$ and low NP level where it increased over time (Fig. 1b). Similarly to decomposition rates, oxygen consumption rates were stimulated by high NP level only at $15^{\circ} \mathrm{C}$ (peak values: $0.26 \mathrm{mg} \mathrm{O}_{2} \mathrm{~g}^{-1} \mathrm{DMh}^{-1}$ at low NP vs. $0.40 \mathrm{mg} \mathrm{O}_{2} \mathrm{~g}^{-1} \mathrm{DMh}^{-1}$ at high NP; Tukey's HSD, $P<0.001$ ). For both nutrient levels, oxygen consumption rates were also higher at $15^{\circ} \mathrm{C}$ than at lower temperatures $\left(15>5^{\circ} \mathrm{C}\right.$ at low NP level; $15>10^{\circ} \mathrm{C}$ and $15>5^{\circ} \mathrm{C}$ at high NP; Tukey's HSD, $P<0.002$; Table 2). When temperature and NP level were increased simultaneously as in a future scenario of both warming and eutrophication in winter (increase from $5{ }^{\circ} \mathrm{C}$ and low $\mathrm{NP}$ to $10^{\circ} \mathrm{C}$ and high NP) or spring (increase from $10^{\circ} \mathrm{C}$ and low NP to $15^{\circ} \mathrm{C}$ and high NP) oxygen consumption rates also increased (Tukey's HSD, $P<0.015$; Table 2).

\section{Mycelial biomass}

Mycelial biomass increased over time for all treatments, attaining maximum values between $24 \mathrm{mg} \mathrm{g}^{-1} \mathrm{DM}$ (at $5^{\circ} \mathrm{C}$ and low NP) and $86 \mathrm{mg} \mathrm{g}^{-1} \mathrm{DM}$ (at $15^{\circ} \mathrm{C}$ and high NP; Fig. 1c). Mycelial biomass was stimulated by high $\mathrm{NP}$ level at 10 and $15^{\circ} \mathrm{C}$ (maximum values: $32 \mathrm{mg} \mathrm{g}^{-1}$
DM vs. $82 \mathrm{mg} \mathrm{g}^{-1} \mathrm{DM}$ at $10^{\circ} \mathrm{C}$ for low and high NP, respectively; $44 \mathrm{mg} \mathrm{g}^{-1} \mathrm{DM}$ vs. $86 \mathrm{mg} \mathrm{g}^{-1} \mathrm{DM}$ at $15^{\circ} \mathrm{C}$; Tukey's HSD, $P<0.020$ ), but not at $5^{\circ} \mathrm{C}$. Mycelial biomass increased with increasing temperature for both NP levels $\left(15>10>5^{\circ} \mathrm{C}\right.$; Tukey's HSD, $P<0.001$; Table 2). Additionally, mycelial biomass at $10^{\circ} \mathrm{C}$ and high $\mathrm{NP}$ level resembled that at $15^{\circ} \mathrm{C}$ and low NP level (Tukey's HSD, $P=0.641$ ), and both were higher than that at $10^{\circ} \mathrm{C}$ and low NP level (Tukey's HSD, $P<0.014$ ), which indicate similar effects of a $5{ }^{\circ} \mathrm{C}$ increase in water temperature or 10-fold increase in NP level for mycelial biomass in systems initially at $10^{\circ} \mathrm{C}$ and low NP level (Table 2). Also, when temperature and NP level were increased simultaneously, in a scenario combining warming and eutrophication in winter or spring, mycelial biomass also increased (Tukey's HSD, $P<0.001$; Table 2).

\section{Fungal sporulation}

Fungal sporulation rates from sacrificed microcosms increased, reached a peak and then decreased $\left(\right.$ at $10^{\circ} \mathrm{C}$ and high NP and at $15^{\circ} \mathrm{C}$ and both NP) or increased continuously over time $\left(\right.$ at $5{ }^{\circ} \mathrm{C}$ and both $\mathrm{NP}$ and $10^{\circ} \mathrm{C}$ and low NP; Fig. 1d). Maximum sporulation rates were attained at $15^{\circ} \mathrm{C}$ and high NP level (2637 conidia $\mathrm{mg}^{-1} \mathrm{DM} \mathrm{day}^{-1}$ ). Sporulation rates were stimulated by high NP level at 10 and $15^{\circ} \mathrm{C}$ (peak values: 620 con- 


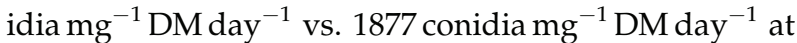
$10^{\circ} \mathrm{C}$ for low and high NP, respectively; 587 conidia mg ${ }^{-1} \mathrm{DMday}^{-1}$ vs. 2637 conidia $\mathrm{mg}^{-1} \mathrm{DM} \mathrm{day}^{-1}$ at $15^{\circ} \mathrm{C}$; Tukey's HSD, $P<0.020$ ), but not at $5^{\circ} \mathrm{C}$. Sporulation rates increased with increasing temperature at both NP levels $\left(15>10>5^{\circ} \mathrm{C}\right.$; Tukey's HSD, $P<0.001$; Table 2). Additionally, and in similitude to mycelial biomass, sporulation rates at $10^{\circ} \mathrm{C}$ and high NP level resembled those at $15^{\circ} \mathrm{C}$ and low NP level (Tukey's HSD, $P=0.947)$, and both were higher than those at $10^{\circ} \mathrm{C}$ and low NP level (Tukey's HSD, $P<0.001$ ), which indicate similar effects of a $5{ }^{\circ} \mathrm{C}$ increase in water temperature or 10-fold increase in NP level for sporulation rates in systems initially at $10^{\circ} \mathrm{C}$ and low NP level. When both temperature and NP level were increased, in a scenario combining warming and eutrophication in winter or spring, sporulation rates also increased (Tukey's HSD, $P<0.001$; Table 2).

The mass of conidia produced per microcosm tended to increase over time, although at higher temperatures (10 and $15^{\circ} \mathrm{C}$ ) and NP level a first peak was reached by day 25 and then a second one close to the end of the experiment. At $15^{\circ} \mathrm{C}$ and low NP level a peak was reached by day 22 (Fig. 2a). Conidial mass production was stimulated at high NP level at 10 and $15^{\circ} \mathrm{C}$ (Tukey's HSD, $P<0.047$ ), but not at $5^{\circ} \mathrm{C}$; conidial production was higher at 10 and $15^{\circ} \mathrm{C}$ than at $5^{\circ} \mathrm{C}$, but only at high NP level (Tukey's HSD, $P<0.001$; Table 3). This translated into cumulative conidial mass production being higher at 10 and $15^{\circ} \mathrm{C}$ and high NP level than at the other four treatments (Tukey's HSD, $P<0.020$; Fig. $2 b$ ). The same patterns (data not shown) and statistical differences were found when considering the number of conidia per microcosm. When temperature and NP level were increased simultaneously, in a future scenario combining warming and eutrophication in winter, total conidial production was stimulated to a higher extent than that predicted from the sum of the effects of both factors considered individually $\left(1.205 \mathrm{mg} \mathrm{microcosms}^{-1}\right.$ observed vs. 0.644 predicted, and 2655703 conidia microcosms $^{-1}$ observed vs. 1328238 predicted; Fig. 2b, Table 4). Sporulating species richness increased until the maximum value, i.e. six, was attained at day 13 at $15^{\circ} \mathrm{C}$, day 22 at $10^{\circ} \mathrm{C}$ and day 25 at $5^{\circ} \mathrm{C}$, which translated into statistical differences among treatments (Fig. 2c, Table 3).

The assemblages of aquatic hyphomycetes associated with alder discs at each sampling date differed among treatments. However, the factor that most affected the structures of assemblages varied among sampling dates: temperature was the most important factor up to day 25, while nutrient level became more important afterwards (Table 5). The total number of conidia produced by each species over 43 days differed among treatments (except for ARTE; two-way ANOVA, $P>0.243$;
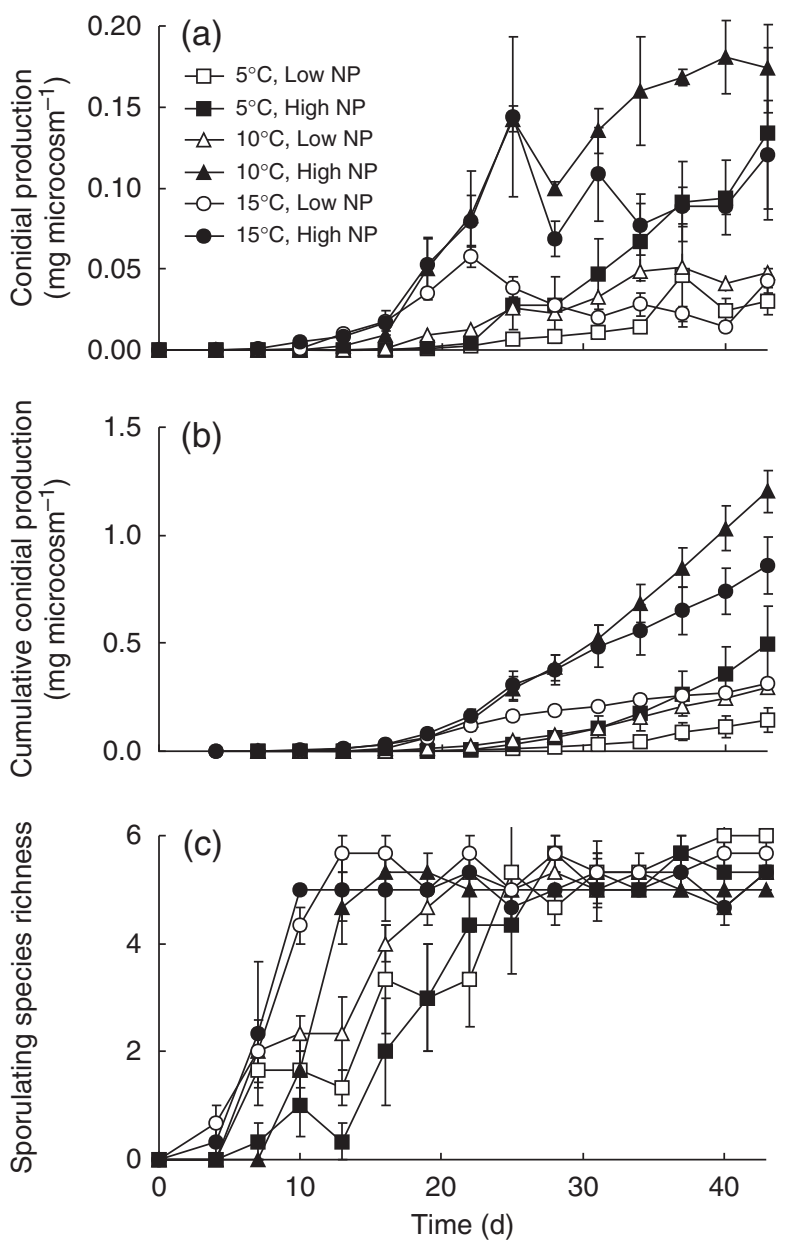

Fig. 2 Conidial production (a), cumulative conidial production (b) and sporulating species richness (c) associated with alder leaf discs incubated in microcosms at three temperatures and two NP levels for 43 days. Data are from microcosms sampled over time and treatments are as in Table 1 . Values are averages \pm 1 SE. The same patterns were found when conidial production and cumulative conidial production were based on the number of conidia per microcosm.

Table 4). On the one hand, individual conidial production at low NP level did not differ among temperatures, while it was generally higher at 10 and / or $15^{\circ} \mathrm{C}$ than at $5^{\circ} \mathrm{C}$ at high NP level. On the other hand, higher NP level stimulated specific conidial production at $5{ }^{\circ} \mathrm{C}$ (HELU and TUAQ), $10^{\circ} \mathrm{C}$ (CLAQ, FLCU and HELU) and $15^{\circ} \mathrm{C}$ (CLAQ, HELU and TEMA; Table 4). ARTE was the least sporulating species at all treatments, while FLCU was by far the dominant species, except at high NP level at 5 and $15^{\circ} \mathrm{C}$ where it co-dominated with HELU and CLAQ, respectively. TEMA and TUAQ ranked third to fifth in dominance (based on conidial production), while HELU and CLAQ ranked first to 
Table 3 Summary table for repeated measures ANOvAs performed on conidial production per microcosm $[\log (x+1)$ transformed] and sporulating species richness, associated with alder discs incubated in microcosms at three temperatures and two NP levels for 43 days

\begin{tabular}{|c|c|c|c|c|c|}
\hline & \multirow[b]{2}{*}{ Df } & \multicolumn{2}{|c|}{ Conidial production } & \multicolumn{2}{|c|}{ Species richness } \\
\hline & & $F$ & $P$ & $F$ & $P$ \\
\hline \multicolumn{6}{|l|}{ Repeated measures ANOVA } \\
\hline Intercept & 1 & 11414.0 & $<0.001$ & 4825.5 & $<0.001$ \\
\hline Temperature & 2 & 59.9 & $<0.001$ & 25.9 & $<0.001$ \\
\hline NP level & 1 & 15.8 & 0.002 & 2.6 & 0.131 \\
\hline Temperature $\times$ NP level & 2 & 4.5 & 0.035 & 1.3 & 0.301 \\
\hline Error & 12 & & & & \\
\hline Time & 12 & 321.9 & $<0.001$ & 52.3 & $<0.001$ \\
\hline Time $\times$ temperature & 24 & 28.4 & $<0.001$ & 8.6 & $<0.001$ \\
\hline Time $\times$ NP level & 12 & 7.3 & $<0.001$ & 1.0 & 0.472 \\
\hline Time $\times$ temperature ${ }^{*} \mathrm{NP}$ level & 24 & 6.1 & $<0.001$ & 2.1 & 0.004 \\
\hline Error & 144 & & & & \\
\hline \multicolumn{6}{|l|}{ Tukey's HSD } \\
\hline $5^{\circ} \mathrm{C}$, low NP & & & $a b$ & & $a b$ \\
\hline $5^{\circ} \mathrm{C}$, high NP & & & a & & $\mathrm{a}$ \\
\hline $10^{\circ} \mathrm{C}$, low NP & & & $\mathrm{bc}$ & & $a b c$ \\
\hline $10^{\circ} \mathrm{C}$, high NP & & & de & & bcd \\
\hline $15^{\circ} \mathrm{C}$, low $\mathrm{NP}$ & & & $\mathrm{cd}$ & & $\mathrm{d}$ \\
\hline $15^{\circ} \mathrm{C}$, high $\mathrm{NP}$ & & & $\mathrm{e}$ & & $\mathrm{cd}$ \\
\hline
\end{tabular}

Tukey's HSD are presented, with treatments with the same letter not being significantly different $(P>0.05)$. Data are from microcosms sampled over time and treatments are as in Table 1.

Table 4 Specific and total number of conidia produced at three temperatures and two NP levels over 43 days

\begin{tabular}{|c|c|c|c|c|c|c|}
\hline \multirow[b]{2}{*}{ Aquatic hyphomycete species } & \multicolumn{2}{|l|}{$5^{\circ} \mathrm{C}$} & \multicolumn{2}{|l|}{$10^{\circ} \mathrm{C}$} & \multicolumn{2}{|l|}{$15^{\circ} \mathrm{C}$} \\
\hline & Low NP & High NP & Low NP & High NP & Low NP & High NP \\
\hline ARTE & $5123^{\mathrm{a}}$ & $4197^{\mathrm{a}}$ & $571^{\mathrm{a}}$ & $872^{\mathrm{a}}$ & $2935^{\mathrm{a}}$ & $2644^{a}$ \\
\hline CLAQ & $20540^{\mathrm{a}}$ & $168914^{\mathrm{a}}$ & $145470^{\mathrm{a}}$ & $570277^{\mathrm{b}}$ & $192317^{\mathrm{a}}$ & $642742^{\mathrm{b}}$ \\
\hline FLCU & $320581^{\mathrm{a}}$ & $293411^{\mathrm{a}}$ & $369380^{\mathrm{a}}$ & $1053139^{\mathrm{b}}$ & $230251^{\mathrm{a}}$ & $527769^{a}$ \\
\hline HELU & $61346^{\mathrm{a}}$ & $344479^{\mathrm{bc}}$ & $64714^{\mathrm{a}}$ & $312743^{\mathrm{b}}$ & $100665^{\mathrm{a}}$ & $452333^{c}$ \\
\hline TEMA & $22759^{a}$ & $42384^{\mathrm{a}}$ & $64215^{\mathrm{ab}}$ & $316422^{\mathrm{bc}}$ & $76999^{\mathrm{ab}}$ & $402410^{c}$ \\
\hline TUAQ & $40787^{\mathrm{a}}$ & $210371^{\mathrm{bc}}$ & $91266^{\mathrm{abc}}$ & $402250^{c}$ & $93038^{\mathrm{abc}}$ & $75032^{\mathrm{ab}}$ \\
\hline Total number of conidia produced & $471136^{\mathrm{a}}$ & $1063757^{\mathrm{a}}$ & $735617^{\mathrm{a}}$ & $2655703^{b}$ & $696206^{\mathrm{a}}$ & $2102930^{\mathrm{b}}$ \\
\hline
\end{tabular}

Data are average values from replicate microcosms sampled over time, and treatments are as in Table 1. Treatments with the same letter are not significantly different (Tukey's HSD, $P>0.05$ ).

ARTE, Articulospora tetracladia; CLAQ, Clavariopsis aquatica; FLCU, Flagellospora curvula; HELU, Heliscus lugdunensis; TEMA, Tetracladium marchalianum; TUAQ, Tumularia aquatica.

fifth being favored at $5^{\circ} \mathrm{C}$ and at 10 and $15^{\circ} \mathrm{C}$, respectively (Fig. 3).

\section{Fungal carbon budgets}

Leaf $\mathrm{C}$ directed to fungal production ranged 6-22\%, and although it was not stimulated by high NP level within any temperature, or by increasing temperature at any
NP level (Tukey's HSD, $P>0.050$ ), it was significantly higher at 10 and $15^{\circ} \mathrm{C}$ and high NP level than at $5{ }^{\circ} \mathrm{C}$ and low NP level (20-22\% vs. 6\%; Tukey's HSD, $P<0.023$; Table 6). Leaf $C$ loss due to mineralization was stimulated at higher temperature for the high NP level only $\left(37 \%\right.$ at $15^{\circ} \mathrm{C}$ vs. $19 \%$ at $5{ }^{\circ} \mathrm{C}$; Tukey's HSD, $P=0.039$ ). Fungal production efficiency was relatively high (31-50\%), and seemed to be stimulated at high NP 
Table 5 Summary table for two-way ANOSIM performed on aquatic hyphomycete assemblages associated with alder discs incubated in microcosms at three temperatures and two NP levels for 43 days

\begin{tabular}{llllll}
\hline \multirow{2}{*}{$\begin{array}{l}\text { Sampling } \\
\text { day }\end{array}$} & \multicolumn{2}{l}{ Temperature } & & \multicolumn{2}{l}{ NP level } \\
\cline { 2 - 3 } & Overall $R$ & $P$ & & Overall $R$ & $P$ \\
\hline 7 & 0.46 & $0.008^{*}$ & & 0.51 & $0.017^{*}$ \\
10 & 0.34 & $0.019^{*}$ & & 0.21 & -0.110 \\
13 & 0.55 & $0.001^{*}$ & & 0.45 & $0.006^{*}$ \\
16 & 0.54 & $0.001^{*}$ & 0.20 & -0.096 \\
19 & 0.60 & $0.001^{*}$ & 0.30 & -0.088 \\
22 & 0.49 & $0.003^{*}$ & 0.17 & -0.182 \\
25 & 0.33 & $0.002^{*}$ & 0.49 & $0.026^{*}$ \\
28 & 0.45 & $0.001^{*}$ & 0.57 & $0.007^{*}$ \\
31 & 0.29 & $0.004^{*}$ & 0.53 & $0.003^{*}$ \\
34 & 0.33 & $0.005^{*}$ & 0.44 & $0.004^{*}$ \\
37 & 0.35 & $0.011^{*}$ & 0.42 & $0.027^{*}$ \\
40 & 0.34 & $0.001^{*}$ & 0.59 & $0.002^{*}$ \\
43 & 0.15 & -0.088 & 0.41 & $0.011^{*}$ \\
\hline
\end{tabular}

Data are from microcosms sampled over time. Overall $R$ gives an absolute measure of how separate the groups are $(0$, indistinguishable; 1 , all similarities within groups are less than any similarity between groups; Clarke \& Gorley, 2001).

*Denote significant effects.

ANOSIM, analysis of similarity.

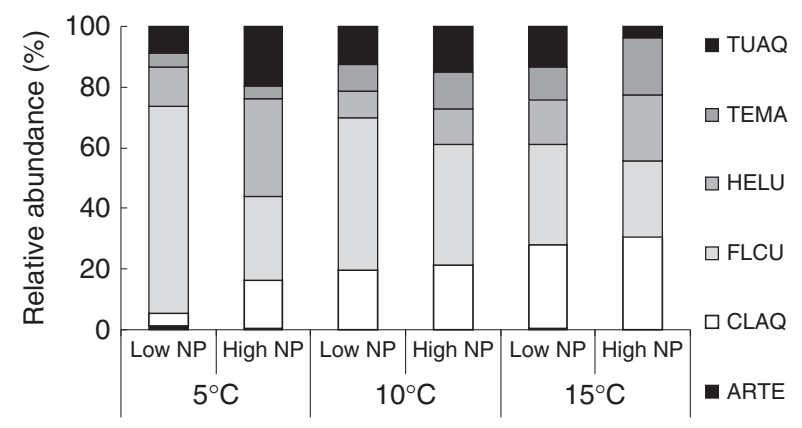

Fig. 3 Relative contribution of fungal species to the total conidial production at three temperatures and two NP levels over 43 days. Data are from microcosms sampled over time and treatments are as in Table 1.

level, although no significant differences were found among treatments (two-way ANOVA, $P>0.130$ ). Mass loss attributed to fungi varied between $26 \%$ and $57 \%$, and although there was a tendency to increase with increasing temperature and NP level, it was only significantly higher at $15^{\circ} \mathrm{C}$ and high NP level than at $5{ }^{\circ} \mathrm{C}$ and low NP level (Tukey's HSD, $P=0.027$ ). As a consequence, leaf $C$ loss as fine particulate and dissolved organic matter (total leaf $\mathrm{C}$ loss minus leaf $\mathrm{C}$ loss due to fungi) varied between $43 \%$ and $74 \%$ in the opposite direction.

\section{Discussion}

The individual effects of water temperature and nutrient concentrations on decomposers and litter decomposition have been widely studied, with most studies reporting a stimulation of decomposers biomass and activity (litter decomposition included) with increasing temperature or nutrient concentrations (see Introduction). However, as far as we know, the combined effects of these two global change factors on litter decomposition in aquatic environments has not yet been addressed, even though they are predicted to increase simultaneously in the near future (Murdoch et al., 2000; MEA, 2005), which might have profound effects in the carbon cycle (Clark, 2004; Knorr et al., 2005; Cornelissen et al., 2007). Here we aimed at assessing the combined effect of increased water temperature, in an attempt to simulate future warming in winter (increase from 5 to $10^{\circ} \mathrm{C}$ ) and spring (increase from 10 to $15^{\circ} \mathrm{C}$ ) (Stefan \& Sinokrot, 1993; Eaton \& Scheller, 1996), and nutrients enrichment, in an attempt to simulate future eutrophication as expected from decreased stream discharges, resulting from increased evapotranspiration and water abstraction for human uses, and increased nutrients loads (Murdoch et al., 2000), on litter decomposition and associated fungal assemblages.

Overall, responses of fungal biomass, activity and consequently decomposition rates, to increased temperature and nutrient concentrations were consistent. On the one hand, the stimulation of all biological variables at high NP level only at high temperatures (10 and/or $15^{\circ} \mathrm{C}$ ) indicates that nutrient enrichment of stream water will have a higher stimulatory effect on fungal performance and decomposition rates under a warming scenario than at lower temperatures. On the other hand, the stimulation of fungal biomass and sporulation with increasing temperature at both NP levels suggests that the predicted increase in water temperature will enhance fungal growth and reproduction in both oligotrophic and eutrophic streams. The stimulation of fungal oxygen consumption and litter decomposition with increasing temperature at high NP level might indicate that a stimulation of carbon mineralization will probably occur at eutrophied streams, while oligotrophic conditions seem to require a $10^{\circ} \mathrm{C}$ (from 5 to $15^{\circ} \mathrm{C}$ ) increase in water temperature to result in stimulated fungal respiration and litter decomposition. Since predictions indicate a maximum increase of $6.4^{\circ} \mathrm{C}$ in atmospheric temperature for this century (Stefan \& Sinokrot, 1993; Eaton \& Scheller, 1996; IPCC, 2007), litter decomposition in oligotrophic streams 
Table 6 Carbon budgets for the fungal assemblage associated with alder discs incubated in microcosms at three temperatures and two NP levels for 43 days

\begin{tabular}{|c|c|c|c|c|c|c|}
\hline & \multicolumn{2}{|l|}{$5^{\circ} \mathrm{C}$} & \multicolumn{2}{|l|}{$10^{\circ} \mathrm{C}$} & \multicolumn{2}{|l|}{$15^{\circ} \mathrm{C}$} \\
\hline & Low NP & High NP & Low NP & High NP & Low NP & High NP \\
\hline Leaf $\mathrm{C}$ loss $(\%)$ & $21.4 \pm 8.0$ & $30.3 \pm 4.0$ & $30.6 \pm 0.7$ & $43.3 \pm 2.1$ & $32.1 \pm 1.0$ & $48.9 \pm 2.6$ \\
\hline Total conidial production $\left(\mathrm{mg} \mathrm{C}^{-1}\right.$ initial leaf $\left.\mathrm{C}\right)$ & $1.7 \pm 0.6$ & $5.2 \pm 1.8$ & $3.5 \pm 0.3$ & $13.0 \pm 1.3$ & $3.5 \pm 0.2$ & $9.9 \pm 1.7$ \\
\hline Leaf $C$ loss due to conidial production $(\%)$ & $0.9 \pm 0.2^{\mathrm{a}}$ & $1.6 \pm 0.3^{\mathrm{ab}}$ & $1.1 \pm 0.1^{\mathrm{ab}}$ & $3.0 \pm 0.3^{c}$ & $1.1 \pm 0.1^{\mathrm{ab}}$ & $2.0 \pm 0.3^{\mathrm{bc}}$ \\
\hline Mycelial biomass ( $\mathrm{mg} \mathrm{Cg}^{-1}$ initial leaf $\mathrm{C}$ ) & $16.0 \pm 9.6$ & $40.3 \pm 14.6$ & $32.5 \pm 0.3$ & $82.4 \pm 7.1$ & $43.7 \pm 3.2$ & $86.5 \pm 17.4$ \\
\hline Leaf $C$ loss due to mycelial production $(\%)$ & $5.5 \pm 2.8^{\mathrm{a}}$ & $12.6 \pm 2.8^{\mathrm{a}}$ & $10.6 \pm 0.3^{\mathrm{a}}$ & $19.3 \pm 2.6^{\mathrm{a}}$ & $13.7 \pm 1.1^{\mathrm{a}}$ & $17.5 \pm 2.9^{\mathrm{a}}$ \\
\hline $\begin{array}{l}\text { Cumulative fungal production } \\
\left(\mathrm{mgC}^{-1} \text { initial leaf } \mathrm{C}\right)^{*}\end{array}$ & $17.7 \pm 10.1$ & $45.5 \pm 16.3$ & $35.9 \pm 0.2$ & $95.4 \pm 7.1$ & $47.2 \pm 3.4$ & $96.4 \pm 18.9$ \\
\hline Yield coefficient $(\%) \dagger$ & $6.4 \pm 2.7^{\mathrm{a}}$ & $14.2 \pm 3.1^{\mathrm{ab}}$ & $11.8 \pm 0.3^{\mathrm{ab}}$ & $22.3 \pm 2.7^{\mathrm{b}}$ & $14.8 \pm 1.2^{\mathrm{ab}}$ & $19.5 \pm 3.1^{\mathrm{b}}$ \\
\hline Respiration $\left(\mathrm{mg} \mathrm{Cg}^{-1}\right.$ initial leaf $\left.\mathrm{C}\right) \ddagger$ & 29.0 & 55.2 & 65.5 & 93.3 & 104.1 & 180.3 \\
\hline Leaf $C$ loss due to mineralization (\%) & $19.4 \pm 8.4^{\mathrm{a}}$ & $18.8 \pm 2.2^{\mathrm{a}}$ & $21.4 \pm 0.5^{\mathrm{ab}}$ & $21.7 \pm 1.1^{\mathrm{ab}}$ & $32.5 \pm 1.0^{\mathrm{ab}}$ & $37.1 \pm 1.9^{\mathrm{b}}$ \\
\hline Production efficiency $(\%) \S$ & $31.4 \pm 15.2^{\mathrm{a}}$ & $42.6 \pm 8.0^{\mathrm{a}}$ & $35.4 \pm 0.1^{\mathrm{a}}$ & $50.4 \pm 1.9^{\mathrm{a}}$ & $31.1 \pm 1.6^{\mathrm{a}}$ & $34.2 \pm 4.6^{\mathrm{a}}$ \\
\hline Explained mass loss $(\%)$ & $25.8 \pm 5.7^{\mathrm{a}}$ & $33.0 \pm 1.0^{\mathrm{ab}}$ & $33.2 \pm 0.8^{\mathrm{ab}}$ & $43.9 \pm 3.7^{\mathrm{ab}}$ & $47.3 \pm 1.9^{\mathrm{ab}}$ & $56.6 \pm 2.6^{\mathrm{b}}$ \\
\hline
\end{tabular}

Values are averages $\pm 1 \mathrm{SE}$. Data are from sacrificed microcosms and treatments are as in Table 1. Treatments with the same letter are not significantly different (Tukey's HSD, $P>0.05$ ).

*Total conidial production + mycelial production.

$\dagger$ Cumulative fungal production $(\%) /$ mass loss $(\%) \times 100$.

$\ddagger$ There is no SE present as values are based on cumulative values by the last sampling date for different microcosms sampled at four dates.

§Cumulative fungal production/(cumulative fungal production + respiration) $\times 100$.

ๆ[Cumulative fungal production $(\%)+$ respiration $(\%)] /$ mass loss $(\%) \times 100$.

might be 'protected', at least to some extent, from global warming. This is further supported by the absence of a relationship between remaining mass after 43 days and water temperature at low NP level, while it was significant and negative at high NP level. These observations result from fungal performance being controlled by temperature, as all biological processes since increased temperature up to an optimum stimulates enzyme activity (Brown et al., 2004), and dissolved nutrients, as these are more readily accessible to microorganisms than those from litter substrates (Suberkropp, 1998), which means that if one of these factors is limiting an increase in the other may not result in a stimulation of fungal performance and litter decomposition. This allows us to speculate that if water quality of presently eutrophied streams is improved with a reduction in nutrient concentrations, the potential stimulatory effects of future increase in water temperature on aquatic biota and processes might be mitigated.

The sensitivities of decomposition rates to temperature $\left(Q_{10-q}\right)$ were higher at lower temperature $\left(5-10^{\circ} \mathrm{C}\right)$ than at higher temperature $\left(10-15^{\circ} \mathrm{C}\right)$ which agrees with previous reports from terrestrial systems (Chen et al., 2000; Bekku et al., 2003), and are explained by a temperature limitation of enzymatic activity. In terrestrial systems, sensitivities of decomposition rates to temperature have been shown to be controlled by other factors as litter quality (Fierer et al., 2005; Conant et al., 2008) and soil nutrient content (Fierer et al., 2003). In our study, sensitivities to temperature differed between NP levels, indicating that dissolved nutrients can also modulate temperature sensitivities of organic matter processing in streams. The general pattern indicates (slightly) higher temperature sensitivity at high NP level $\left(Q_{10-q}=1.49\right.$ and 1.36 for high and low NP, respectively, from 5 to $15^{\circ} \mathrm{C}$ ), as expected when nutrients are not limiting. However, when only an increase in water temperature from 5 to $10^{\circ} \mathrm{C}$ was considered, decomposition was stimulated to a higher extent at low NP level than at high NP level, which remains difficult to explain without considering consequences of modified interspecific interactions.

Another aspect to be noted is that for fungal biomass and sporulation rate at $10^{\circ} \mathrm{C}$ and low NP level, a 10-fold increase in nutrient concentrations was equivalent to a $5{ }^{\circ} \mathrm{C}$ increase in water temperature, indicating that in some cases the effects of warming will resemble those of eutrophication, and some presently eutrophied streams might serve as models to predict the effects of future warming on similar noneutrophied streams. However, predictions are that water temperature and nutrient concentrations will increase simultaneously in many streams, unless efficient measures to reduce water abstraction from and nutrients loads to streams are 
undertaken (Murdoch et al., 2000; MEA, 2005). In such a scenario, all biological variables assessed here will be stimulated, independently of the original water temperature, as a result of synergistic interactions between increased temperature and nutrient enrichment. This might have profound impacts on forest streams where decomposition of allochthonous organic matter is at the base of aquatic food webs. Changes in fungal growth and activity, including litter decomposition, might lead to altered energy and nutrient flow through the food chain (Greenwood et al., 2006), and might affect aquatic organisms that have their life cycles synchronized with the autumnal litter supply in temperate regions (Bärlocher, 2000; Gulis \& Suberkropp, 2004). Faster decomposition of organic matter under warmer and nutrient rich conditions will lead to its earlier disappearance from the stream bed which can result in food depletion for higher trophic levels. However, this is still difficult to predict, with the increase in atmospheric $\mathrm{CO}_{2}$ concentration, besides being responsible for an increase in temperature, also possibly leading to an increase in leaf production but of poorer quality (Norby et al., 2001; Stiling \& Cornelissen, 2007), which might counteract the faster litter decomposition predicted here.

In addition to the described alterations on fungal biomass and activity, increased water temperature and nutrient levels also affected the structure of aquatic hyphomycete assemblages, but their relative importance varied over time. Water temperature was more important during the initial colonization of leaf discs by fungal species, leading to faster colonization of discs at higher temperature. However, this can not simply be attributed to differences in temperature tolerances of species since eventually all species sporulated at all temperatures and overall conidial production (number and mass) did not differ among temperatures at low NP level. Actually, the fact that all six species sporulated at all treatments indicates that conidia germinated and mycelia grew from all species within the $24 \mathrm{~h}$ period of leaf inoculation with the combined conidial suspension (Dang et al., 2007, 2009). The delay in sporulation at lower temperatures might be explained by a delay in biomass built-up; although sporulation rates usually peak before mycelial biomass (Suberkropp \& Chauvet, 1995; Gulis et al., 2006; Lecerf \& Chauvet, 2008), they can be delayed until enough biomass accumulates (Gonçalves et al., 2007). Also, none of the six species of aquatic hyphomycetes used here were markedly coldor warm-water species, except TEMA which is known to grow and sporulate best at high temperatures $\left(25^{\circ} \mathrm{C}\right.$; Chauvet \& Suberkropp, 1998), although here its overall sporulation did not differ among temperatures. However, temperature might have changed interspecific relationships (Webster et al., 1976), which translated into modifications in species rank in a dominance scale, with CLAQ acquiring competitive advantage and HELU and TUAQ loosing it with increasing temperature. Changes in communities dominance induced by temperature have been observed before (Bärlocher et al., 2008; Dang et al., 2009). After day 25, when all species were sporulating at all treatments, NP level became more important than temperature leading to overall higher conidial production at high NP level (Suberkropp \& Chauvet, 1995; Gulis \& Suberkropp, 2003a, b; Ferreira et al., 2006b). Surprisingly, ARTE conidial production did not differ between NP levels, although it was previously reported to be stimulated by increasing nutrient concentrations in microcosms (Gulis \& Suberkropp, 2003b) and in a whole-stream nitrate addition experiment (Ferreira et al., 2006b). Nutrient enrichment has also been reported to induce shifts in dominance of fungal communities, maybe due to changes in species interactions (Gulis \& Suberkropp, 2003a; Pascoal et al., 2005a; Ferreira et al., 2006b; Artigas et al., 2008). These shifts also occurred here within each treatment, with CLAQ being favored and FLCU unflavored by increased NP level at 5 and $15^{\circ} \mathrm{C}$. Changes in dominance rank of HELU, TEMA and TUAQ also occurred with increasing NP level, but the direction of these changes depended on water temperature. Although aquatic hyphomycete assemblages have been considered functionally redundant (Dang et al., 2005; Pascoal et al., 2005a,b; Ferreira et al., 2006a), shifts in assemblage composition and identity of the dominant species might have indirect effects on litter decomposition since aquatic detritivores derive a large portion of $C$ from fungal mycelium (Chung \& Suberkropp, 2009), and seem to have preferences for certain fungal species (Suberkropp et al., 1983). This might result in differential performances when invertebrates feed on different fungal species (Arsuffi \& Suberkropp, 1986), which might lead to differential invertebrate induced decomposition rates of leaves with different dominant fungal species (Arsuffi \& Suberkropp, 1984). Additionally, if changes in temperature and trophic state of freshwaters lead to decreases in fungal species richness, either because they reach their upper thermal tolerance limit or due to exclusion by competition, this might negatively affect invertebrate performance (Lecerf et al., 2005) with further consequences for ecosystem functioning.

Carbon budgets for fungi associated with decomposing alder leaf discs were similar to those reported in previous studies (Baldy et al., 1995; Baldy \& Gessner, 1997; Gulis \& Suberkropp, 2003b, c; Pascoal \& Cássio, 2004; Pascoal et al., 2005b). Fungal production was responsible for $6-22 \%$ of leaf $\mathrm{C}$ mass loss; however, a larger portion of leaf $\mathrm{C}$ mass loss was due to fungal respiration (19-37\%). Nevertheless, fungal production 
efficiency was high (31-50\%). Overall, fungi were responsible for $26-57 \%$ of the initial leaf C mass loss, which adds to the large body of evidence indicating aquatic hyphomycetes as important players in litter processing (Baldy et al., 1995; Hieber \& Gessner, 2002; Gulis \& Suberkropp, 2003c; Pascoal et al., 2005b), and their importance to leaf mass loss clearly increased with increasing temperature and nutrient concentrations (Gulis \& Suberkropp, 2003b; this study). An important amount of leaf $\mathrm{C}$ mass was also lost from the system as fine particulate and dissolved organic matter (43-74\% in this study; Gulis \& Suberkropp, 2003b,c), and this pathway was more important at lower temperatures and nutrient concentrations. These modifications of $C$ budgets under simultaneous increases in water temperature and nutrient concentrations might have serious consequences on the functioning of small heterotrophic streams and reaches downstream, as the portion of leaf $\mathrm{C}$ incorporated by fungi will locally increase resulting in higher retention of carbon and nutrients within the system. This, together with the increase in the portion of leaf $C$ respired within the system and the decrease in its loss as fine particulate and dissolved organic matter will impact downstream reaches where collectors become the most abundant functional feeding group (Vannote et al., 1980) and thus may lack appropriate resources. Effects of global change factors on fungal activity and community structure might therefore cascade along the food web, with effects on detritivores and collectors (Greenwood et al., 2006). These might further affect higher trophic levels which depend on these organisms as a food resource.

In conclusion, simultaneous increases of water temperature and nutrient concentrations accelerated decomposition rates of alder leaf discs (up to 52\%, and up to $24 \%$ above expected increases), stimulated fungal growth, reproduction and overall activity, changed the structure of assemblages and altered fungal carbon budgets. Some of these modifications were however attenuated at low nutrient concentrations, which suggest that the recovery of presently eutrophied streams might mitigate the effects of future climate warming on aquatic fungal communities and fungal mediated processes. This suggestion is further supported by previous studies which have demonstrated that water temperature and quality (e.g. nutrient status, acidification) interact to affect aquatic communities structure and processes (Marcarelli \& Wurtsbaugh, 2006; Durance \& Ormerod, 2007), and that improvement of water quality might have delayed changes due to global warming in macroinvertebrate community structure like in the French Rhône River (Daufresne et al., 2007).

\section{Acknowledgements}

We thank Sylvain Lamothe and Didier Lambrigot for isolation of aquatic hyphomycete species and for providing technical help. The comments by two anonymous reviewers on an earlier version of the ms were most appreciated. Financial support granted by the FCT (Portuguese Foundation for Science and Technology, Reference POCTI2010/SFRH/BPD/34368/2006) to V.F. and by the CNRS (National Center for Scientific Research) to E.C. is gratefully acknowledged.

\section{References}

Abelho M, Graça MAS (2006) Effects of nutrient enrichment on decomposition and fungal colonization of sweet chestnut leaves in an Iberian stream (Central Portugal). Hydrobiologia, 560, 239-247.

Arsuffi TL, Suberkropp K (1984) Leaf processing capabilities of aquatic hyphomycetes: interspecific differences and influence on shredder feeding preferences. Oikos, 42, 144-154.

Arsuffi TL, Suberkropp K (1986) Growth of two caddisflies (Trichoptera) on leaves colonized by different fungal species. Journal of the North American Benthological Society, 5, 297-305.

Artigas J, Romaní AM, Sabater S (2008) Effect of nutrients on the sporulation and diversity of aquatic hyphomycetes on submerged substrata in a Mediterranean stream. Aquatic Botany, 88, 32-38.

Azevedo-Pereira HVS, Graça MAS, González JM (2006) Life history of Lepidostoma hirtum in an Iberian stream and its role in organic matter processing. Hydrobiologia, 559, 183-192.

Baldy V, Gessner MO (1997) Towards a budget of leaf litter decomposition in a firstorder woodland stream. Comptes Rendus de l' Académie des Sciences, 320, 747-758.

Baldy V, Gessner MO, Chauvet E (1995) Bacteria, fungi and the breakdown of leaf litter in a large river. Oikos, 74, 93-102.

Baldy V, Gobert V, Guerold F, Chauvet E, Lambrigot D, Charcosset J-Y (2007) Leaf litter breakdown budgets in streams of various trophic status: effects of dissolved inorganic nutrients on microorganisms and invertebrates. Freshwater Biology, 52, 1322-1335.

Bärlocher F (1992) Community organization. In: The Ecology of Aquatic Hyphomycetes (ed. Bärlocher F), pp. 38-76. Springer-Verlag, New York.

Bärlocher F (2000) Water-borne conidia of aquatic hyphomycetes: seasonal and yearly patterns in Catamaran Brook, New Brunswick, Canada. Canadian Journal of Botany, 78, 157-167.

Bärlocher F, Schweizer M (1983) Effects of leaf size and decay rate on colonization by aquatic hyphomycetes. Oikos, 41, 205-210.

Bärlocher F, Seena S, Wilson KP, Williams DD (2008) Raised water temperature lowers diversity of hyporheic aquatic hyphomycetes. Freshwater Biology, 53, 368-379.

Baulch HM, Schindler DW, Turner MA, Findlay DL, Paterson MJ, Vinebrooke RD (2005) Effects of warming on benthic communities in a boreal lake: implications of climate change. Limnology and Oceanography, 50, 1377-1392.

Beisner BE, MaCauley E, Wrona FJ (1997) The influence of temperature and food chain length on plankton predator-prey dynamics. Canadian Journal of Fisheries and Aquatic Sciences, 54, 586-595.

Bekku YS, Nakatsubo T, Kume A, Adachi M, Koizumi H (2003) Effect of warming on the temperature dependence of soil respiration rate in arctic, temperate and tropical soils. Applied Soil Ecology, 22, 205-210.

Brown JH, Gillooly JF, Allen AP, Savage VM, West GB (2004) Towards a metabolic theory of ecology. Ecology, 85, 1771-1789.

Buzby KM, Perry SA (2000) Modeling the potential effects of climate change on leaf pack processing in central Appalachian streams. Canadian Journal of Fisheries and Aquatic Sciences, 57, 1773-1783.

Carpenter SR, Adams MS (1979) Effects of nutrients and temperature on decomposition of Myriophyllum spicatum L. in a hard-water eutrophic lake. Limnology and Oceanography, 24, 520-528.

Castella E, Adalsteinsson H, Britain JE et al. (2001) Macrobenthic invertebrate richness and composition along a latitudinal gradient of European glacier-fed streams. Freshwater Biology, 46, 1811-1831.

Chauvet E, Suberkropp K (1998) Temperature and sporulation of aquatic hyphomycetes. Applied Environmental Microbiology, 64, 1522-1525. 
Gulis V, Suberkropp K (2003a) Leaf litter decomposition and microbial activity in nutrient-enriched and unaltered reaches of a headwater stream. Freshwater Biology, 48, 123-134.

Gulis V, Suberkropp K (2003b) Interactions between fungi and bacteria associated with decomposing leaf litter at different levels of nutrient availability. Aquatic Microbial Ecology, 30, 147-157.

Gulis V, Suberkropp K (2003c) Effect of inorganic nutrients on relative contributions of fungi and bacteria to carbon flow from submerged decomposing leaf litter Microbial Ecology, 45, 11-19.

Gulis V, Suberkropp K (2004) Effects of whole-stream nutrient enrichment on the concentration and abundance of aquatic hyphomycete conidia in transport Mycologia, 96, 57-65.

Hieber M, Gessner MO (2002) Contribution of stream detritivores, fungi, and bacteria to leaf breakdown based on biomass estimates. Ecology, 83, 1026-1038.

Hoffman JR, Hansen LJ, Klinger T (2003) Interactions between UV radiation and temperature limit inferences from single-factor experiments. Journal of Phycology, 39, $268-272$.

Hogg ID, Williams DD (1996) Response of stream invertebrates to a global-warming thermal regime: an ecosystem-level manipulation. Ecology, 77, 395-407.

IPCC (Intergovernmental Panel on Climate Change) (2007) Climate Change 2007: The Physical Science Basis. Contribution of the Working Group I to the Fourth Assessment Report of the Intergovernmental Panel on Climate Change. Cambridge University Press, Cambridge, UK

Irons JG, Oswood MW, Stout RJ, Pringle CM (1994) Latitudinal patterns in leaf litter breakdown: is temperature really important? Freshwater Biology, 32, 401-411.

Jiang L, Morin PJ (2007) Temperature fluctuation facilitates coexistence of competing species in experimental microbial communities. Journal of Animal Ecology, 76, 660-668.

Knorr W, Prentice IC, House JI, Holland EA (2005) Log-term sensitivity of soil carbon turnover to warming. Nature, 433, 298-205.

Lecerf A, Chauvet E (2008) Diversity and functions of leaf-decaying fungi in human-altered streams. Freshwater Biology, 53, 1658-1672.

Lecerf A, Dobson M, Dang CK, Chauvet E (2005) Riparian plant species loss alters trophic dynamics in detritus-based stream ecosystems. Oecologia, 146, 432-442.

Lecerf A, Usseglio-Polatera P, Charcosset J-Y, Lambrigot D, Bracht B, Chauvet E (2006) Assessment of functional integrity of eutrophic streams using litter breakdown and benthic macroinvertebrates. Archiv für Hydrobiologie, 165, 105-126.

Koske RE, Duncan IW (1974) Temperature effects on growth, sporulation, and germination of some 'aquatic' hyphomycetes. Canadian Journal of Botany, 52, 1387-1391

Marcarelli AM, Wurtsbaugh WA (2006) Temperature and nutrient supply interact to control nitrogen fixation in oligotrophic streams: an experimental examination. Limnology and Oceanography, 51, 2278-2289.

MEA (Millennium Ecosystem Assessment) (2005) Ecosystems and Human Well-Being: Synthesis. Island Press, Washington, DC.

Mouritsen KN, Tompkins DM, Poulin R (2005) Climate warming may cause a parasiteinduced collapse in coastal amphipod populations. Oecologia, 146, 476-483.

Mouthon J, Daufresne M (2006) Effects of the 2003 heatwave and climatic warming on mollusc communities of the Saone: a large lowland river and of its two main tributaries (France). Global Change Biology, 12, 441-449.

Murdoch PS, Baron JS, Miller TL (2000) Potential effects of climate change on surfacewater quality in North America. Journal of the American Water Resources Association, $36,347-366$.

Niyogi DK, Simon KS, Townsend CR (2003) Breakdown of tussock grass in streams along a gradient of agricultural development in New Zealand. Freshwater Biology 48, 1698-1708.

Norby RJ, Cotrufo MF, Ineson P, O’Neill EG, Canadell JG (2001) Elevated $\mathrm{CO}_{2}$, litter chemistry, and decomposition: a synthesis. Oecologia, 127, 153-165.

Pascoal C, Cássio F (2004) Contribution of fungi and bacteria to leaf litter decomposition in a polluted river. Applied Environmental Microbiology, 70, 5266-5273.

Pascoal C, Cássio F, Marvanová L (2005a) Anthropogenic stress may affect aquatic hyphomycete diversity more than leaf decomposition in a low-order stream. Archiv für Hydrobiologie, 162, 481-496.

Pascoal C, Cássio F, Marcotegui A, Sanz B, Gomes P (2005b) Role of fungi, bacteria and invertebrates in leaf litter breakdown in a polluted river. Journal of the North American Benthological Society, 24, 784-797.

Pascoal C, Pinho M, Cássio F, Gomes P (2003) Assessing structural and functional ecosystem condition using leaf breakdown: studies in a polluted river. Freshwater Biology, 48, 2033-2044.

Petchey OL, MaPhearson PT, Casey TM, Morin PJ (1999) Environmental warming alters food-web structure and ecosystem function. Nature, 402, 69-72. 
Pozo J, Colino R (1992) Decomposition processes of Spartina maritima in a salt marsh of the Basque Country. Hydrobiologia, 231, 165-175.

Przeslawski R, Davis AR, Benkendorff K (2005) Synergistic effects associated with climate change and the development of rocky shore molluscs. Global Change Biology, 11, 515-522.

Quinn JM, Steele GL, Hickey CW, Vickers ML (1994) Upper thermal tolerances of twelve New Zealand stream invertebrate species. New Zealand Journal of Marine and Freshwater Research, 28, 391-397.

Rajashekar M, Kaveriappa KM (2000) Effects of temperature and light on growth and sporulation of aquatic hyphomycetes. Hydrobiologia, 441, 149-153.

Rosemond AD, Pringle CM, Ramírez A, Paul MJ, Meyer JL (2002) Landscape variation in phosphorus concentration and effects on detritus-based tropical streams. Limnology and Oceanography, 47, 278-289.

Rozema J, Lenssen GM, van de Staaij JWM, Visser AJ, Broekman RA (1997) Effects of UV-B radiation on terrestrial plants and ecosystems: interaction with $\mathrm{CO}_{2}$ enrichment. Plant Ecology, 128, 183-191.

Stefan HG, Sinokrot BA (1993) Projected global climate change impact on water temperatures in five North Central U.S. streams. Climate Change, 24, 353-381.

Stiling P, Cornelissen T (2007) How does elevated carbon dioxide $\left(\mathrm{CO}_{2}\right)$ affect plantherbivore interaction? A field experiment and meta-analysis of $\mathrm{CO}_{2}$-mediated changes on plant chemistry and herbivore performance. Global Change Biology, 13, 1823-1842.
Suberkropp K (1991) Relationships between growth and sporulation of aquatic hyphomycetes on decomposing litter. Mycology Research, 95, 843-850.

Suberkropp K (1998) Effect of dissolved nutrients on two aquatic hyphomycetes growing on leaf litter. Mycology Research, 102, 998-1002.

Suberkropp K, Arsuffi TL, Anderson JP (1983) Comparison of degradative ability, enzymatic activity, and palatability of aquatic hyphomycetes grown on leaf litter. Applied Environmental Microbiology, 46, 237-244.

Suberkropp K, Chauvet E (1995) Regulation of leaf breakdown by fungi in streams: influences of water chemistry. Ecology, 76, 1433-1445.

Suberkropp K, Weyers H (1996) Application of fungal and bacterial production methodologies to decomposing leaves in streams. Applied Environmental Microbiology, 62, 1610-1615.

Vannote RL, Minshal GW, Cummins KW, Sedall JR, Cushing CE (1980) The river continuum concept. Canadian Journal of Fisheries and Aquatic Sciences, 37, 130-137.

Webster J, Moran ST, Davey RA (1976) Growth and sporulation of Tricladium chaetocladium and Lunulospora curvula in relation to temperature. Transactions of the British Mycological Society, 67, 491-549.

Winterbourn MJ (1969) Water temperature as a factor limiting the distribution of Potamopyrgus antipodarum (Gastropoda-Prosobranchia) in the New Zealand thermal region. New Zealand Journal of Marine and Freshwater Research, 3, 453-458. 